\title{
Geoelectrical and Geotechnical Characterization of Different Types of Soil in Ede, Osun State, Nigeria
}

\author{
${ }^{* 1}$ Wilfred N. Igboama, ${ }^{1}$ Olaide S. Hammed, ${ }^{2}$ Maruf T. Aroyehun and ${ }^{3}$ Nicholas U. Ugwu \\ ${ }^{1}$ Department of Physics, Federal University, Oye-Ekiti, Nigeria \\ ${ }^{2}$ Department of Geophysics, Federal University, Oye-Ekiti, Nigeria \\ ${ }^{3}$ Department of Science Laboratory Technology, Federal Polytechnic, Ede, Nigeria \\ \{wilfred.igboama | olaide.hammed\}@fuoye.edu.ng | maruf.aroyehun.ma@gmail.com | nuumay665@gmail.com \\ Received: 28-MAY-2021; Reviewed: 09-JUN-2021; Accepted: 15-JUN-2021 \\ http://dx.doi.org/10.46792/fuoyejet.v6i2.651
}

\begin{abstract}
Geoelectrical and geotechnical investigations were carried out to characterize soils from different locations in Ede, Osun State, Nigeria for engineering purposes. Wenner electrode configuration technique was deployed in carrying out the geoelectrical survey of about $40 \mathrm{~m}$ for each profile. The data analysis was approached by plotting the apparent conductivity against electrode spacing (s) and the result was interpreted. The geoelectrical resistivity survey revealed locations 1 and 2 with resistivity values of 25.01-419.22ohm-m (conductivity $0.002-0.194(\mathrm{ohm}-\mathrm{m})^{-1}$ and $5.5-1246.57 \mathrm{ohm}-\mathrm{m}$ (conductivity $=0.0002-0.001(\mathrm{ohm}-\mathrm{m})^{-1}$ ) respectively could be classified as clay. Sample 3 recorded a resistivity value of $1.00-22,787.39 \mathrm{ohm}-\mathrm{m}$ (conductivity $=0.00004-1.00(\mathrm{ohm}-\mathrm{m})^{-1}$ ) thus, was classified as silt/sand respectively. Soil from the said different locations in Ede, Nigeria, were tested in the Laboratory for certain properties like Atterberg limits, specific gravities, sieve analysis, compaction test, etc. and the results showed that samples 1,2 and 3 have specific gravity values of $2.50,2.13$ and 2.40 respectively and could therefore be referred to as organic soil. Samples 1,2 and 3 have maximum dry density (MDD) of $1.45 \mathrm{~g} / \mathrm{cm}^{3}, 1.92 \mathrm{~g} / \mathrm{cm}^{3}$, $1.95 \mathrm{~g} / \mathrm{cm}^{3}$ and optimum moisture content (OMC) of $15.40 \%, 13.36 \%$ and $9.61 \%$ respectively. The analysis conducted in this study revealed that the soil type found in Ede, Nigeria could be classified as silt-clay, sandy clay, clay and sand.
\end{abstract}

Keywords- Electrical conductivity, Characterization, Compaction, Plasticity, Wenner array

\section{INTRODUCTION}

The study of earth using the application of Physics principles provides useful information on the earth's interior. This is done by measuring the influence caused by internal distribution of physical properties of the earth at or near the earth surface. Most times, analyses of these results reveal changes in the physical properties of the earth's interior from one point to another and the factors responsible for this variation are always sort for. The application of geophysical methods to soil sciences has been ongoing for a considerable length of time. The collection of data on the area under investigation without altering the physical arrangement is the main idea behind geophysical exploration (Scollar et al., 1990). Hence, it is mostly employed where preservation is considered very important to avoid disturbance of culturally sensitive sites such as cemeteries. Any of the geophysical methods can be employed depending on physical property that would give the desired result.

In this study, the method adopted was based on the electric properties because soil materials and properties are strongly correlated and can be determined through the geoelectrical properties. The measurement of how well the soil conducts electricity is called soil conduction. These measurements can be used in the classification of soil and geologic materials with their locations. Buried items that are metallic in nature can also be identified using these measurements. The variations in conductivity values spread over several orders of magnitude depending on the type of material in contact.

\footnotetext{
${ }^{*}$ Corresponding Author

Section D- CIVIL ENGINEERING \& RELATED SCIENCES

Can be cited as:

Igboama W.N., Hammed O.S., Aroyehun M.T. and Ugwu N.U. (2021): "Geoelectrical and Geotechnical Characterization of Different Types of Soil in Ede, Osun State, Nigeria", FUOYE Journal of Engineering and Technology (FUOYEJET), 6(2), 99-104. http://dx.doi.org/10.46792/fuoyejet.v6i2.651
}

Studies have shown that soil conductivity is dependent on the presence of conductive materials, quantity of pore fluid present, salinity of the fluid and fracturing (Llopis and Simms, 2007). The electrical conductivity of soil was determined by investigating soil salinity (Rhoades et al., 1989). Electrical resistivity as a reciprocal of electrical conductivity is dependent on soil properties. The application of the electrical resistivity method in geophysical measurement was initiated by Conrad Schlumberger in France in 1912 (Dahlin, 2001). In 1915, following the work of Schlumberger, Wenner suggested a linear array of four electrodes having equal space would reduce the problems associated with soil-electrode contact if current electrode is separated from potential electrodes in space. With reference to that time, all measurements deploying electrical resistivity methods in geophysics and soil science were framed on fourelectrode device (equipment).

The electrode arrangement and sequential measurements is called an array and many different arrays have been developed through the years among which are Poledipole, Pole-pole, Dipole-dipole, Wenner and WennerSchlumberger. The Wenner array method of measuring ground conductivity is an electrical technique which requires an introduction of electric current into the earth. For electrical resistivity method, using direct current, the current is supplied directly to the ground through a pair of current electrodes and the output voltage $\mathrm{V}$ is measured between the second pair of potential electrodes. The depth measured is about one third of the distance between the current measuring electrodes. The further the electrode separation, the deeper the depth of investigation. Each of these measurements is known as the apparent resistivity and could be defined as the measurement that would have been taken assuming the entire subsurface was uniform (Everett, 2013). 
Some researchers have worked on soil type identification based on the size of its resistivity. Such people include Piegari and Di Maio (2013) who derived an empirical formular, relating soil resistivity and suction by combining Archie (1942) and Van Gnuchten (1980) models on some of the field and laboratory tests. e Study on the description of the tilled soil structure was conducted by Besson et al., (2004), using electrical resistivity. Seladji et al., (2010) also carried out a study based on the principle of electrical resistivity to determine the effect of soil compaction in the laboratory. Other researchers have carried out several studies on soil classifications based on field resistivity measurements, Kaufman and Hoekstra (2001) and Palacky (1988). Kaufman and Hoekstra (2001) observed that overlaps occur between different soil types based on resistivity values obtained.

Many researchers have established that adverse impact due to the environment, failure in structure or post construction problems can be prevented by adequate design and construction of civil engineering structures (Nwankwoala, et al., 2013; Ngah and Nwankwoala, 2013; Youdeowei et al., 2013 and Oghenero et al., 2014). This can be achieved by knowing the characteristics of soil like compressibility, plasticity, strength of the soil to ensure appropriate design and construction. Construction errors could be due to ill knowledge of the properties of the soil. Engineering characteristics of soil should be known to judge the suitability of such soil for particular use and not to rely on visual inspection.

Engineering properties under controlled environment are easily determined in the laboratory tests with the advantages of measuring directly specifics in a given condition. The process of getting samples through drilling processes or excavation may give result different from values that would be obtained if geophysical (nonintrusive) method is deployed (Huat et al., 2013). The present study therefore, is aimed at characterization of different soils in Ede, Nigeria, on their geoelectrical and geotechnical properties to determine their suitability for engineering and other uses.

\section{THEORY}

According to Lowrie (2007), the Wenner array could be arranged as illustrated in Figure 1. Current electrodes A and $\mathrm{B}$ inject current to the soil and receive current from the soil. The potential at the detection electrode $C$ due to the source $\mathrm{A}$ is $+\rho I /\left(2 \pi r_{A C}\right)$ while the potential due to $\mathrm{B}$ is $-\rho I /\left(2 \pi r_{C B}\right)$. Combining potentials at $C$, we have

$$
U_{C}=\frac{\rho I}{2 \pi}\left(\frac{1}{r_{A C}}-\frac{1}{r_{C B}}\right)
$$

Also, the resultant potential at $\mathrm{D}$ is

$$
U_{D}=\frac{\rho I}{2 \pi}\left(\frac{1}{r_{A D}}-\frac{1}{r_{D B}}\right)
$$

The voltmeter connected between $C$ and $D$ measured the potential difference $\mathrm{V}$ given by

$$
V=\frac{\rho I}{2 \pi}\left(\frac{1}{r_{A C}}-\frac{1}{r_{C B}}\right)-\left(\frac{1}{r_{A D}}-\frac{1}{r_{D B}}\right)
$$

Therefore, the resistivity, is obtained as

$$
\rho=2 \pi \frac{V}{I}\left\{\left(\frac{1}{r_{A C}}-\frac{1}{r_{C B}}\right)-\left(\frac{1}{r_{A D}}-\frac{1}{r_{D B}}\right)\right\}^{-1}
$$

The separations between the electrodes are given as: $r_{A C}=r_{D B}=a$ and $r_{C B}=r_{A D}=2 a$. Putting these values into eq. (4) gives

$$
\begin{aligned}
& \rho=2 \pi \frac{V}{I}\left\{\left(\frac{1}{a}-\frac{1}{2 a}\right)-\left(\frac{1}{2 a}-\frac{1}{a}\right)\right\}^{-1} \\
& \rho=2 \pi a \frac{V}{I}
\end{aligned}
$$

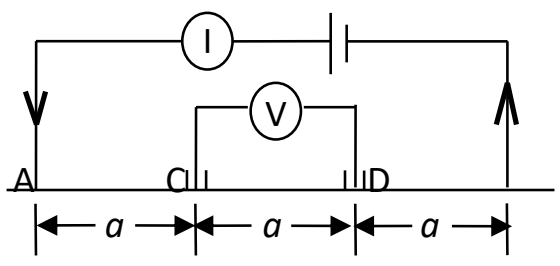

Fig.1: Wenner Electrode arrangement

Equation (6) is the apparent resistivity, $\rho$. The reciprocal of this expression is called the electrical conductivity (7) measured in $\left(\mathrm{Sm}^{-1}\right)$.

Hence,

$$
\sigma=\frac{1}{\rho}
$$

\section{Methodology}

\subsection{GEOELECTRIC INVESTIGATION}

The geoelectrical investigation was carried out at three different locations: location 1 (Ededimeji along Akoda road in Ede), location 2 (Along Iwo-Osogbo Road, Ede) and location 3 at Cocoa Industry/ water cooperation area, Ede, Osun State, Nigeria. Utilizing the Wenner arrangement, four electrodes were hammered into the soil. Electric current (I), generated artificially was sent through two current electrodes into the ground and the output voltage $(\mathrm{V})$ was measured by a pair of potential electrodes. The resistance, $R$ due to soil is given by $R=V / I$. Using this on equation (6) gives the apparent resistivity.

\subsection{LABORATORY ANALYSES}

Three soil samples were gathered from each of the three different locations: location 1 (Ededimeji along laboratory Akoda road Ede), location 2 (Along Iwo-Osogbo Road, Ede) and location 3 at Cocoa Industry/ water cooperation area Ede, Western Nigeria, for laboratory analyses. The samples were bagged in different polythene bags and preserve for geotechnical analysis after moisture content tests had been carried out in the. The following laboratory tests were carried out; water content, Atterberg limits, sieve analysis, compaction tests, etc. and the data for various tests were recorded and necessary deductions were made.

\section{RESULt AND Discussion}

Figure 2 is the graph of profile 1 taken at Ededimeji along Akoda road in Ede. It is the graph of apparent conductivity $\left((\mathrm{ohm}-\mathrm{m})^{-1}\right)$ against electrode separation $(\mathrm{m})$. The figure showed that the conductivity increased with 
increase in electrode separation from 1-2m. Decrease in conductivity occurred down the graph up to separation $12 \mathrm{~m}$ and a slight increase in conductivity occurred as the separation increased. The profile portrayed 3 geo-electric layers. It was observed that this location has high conductivity $0.002-0.194(\mathrm{ohm}-\mathrm{m})^{-1}$ which could be result of different constituents of soil in this portion of land.

Figure 3 is the second profile located Along Iwo-Osogbo Road. It was observed that the conductivity was very high at the first separation and decreased downward as the separation increased. On getting to a point $8 \mathrm{~m}$ from the origin, the conductivity followed a uniform order almost parallel to separation axis showing similar soil characteristics. It was observed that this soil sample has a moderately high conductivity $\left(0.0002-1.00\right.$ (ohm-m) $\left.{ }^{-1}\right)$ which could be as a result of compaction of the soil and which could result from low absorption of water. Figure 4 is the graph of profile 3 at Cocoa industry- water cooperation area. The conductivity along this profile was very high at the first separation and decreased to a very low conductivity across the graph but at separation 6 , that is $8.0 \mathrm{~m}$ from the origin, a slight increase in conductivity was observed. This location was observed to have the lowest conductivity (0.00004- 1.00 (ohm-m)-1); which could be ascribed to lose soil particles or natural constituents of soil in the area.

Based on Palacky (1988), the following range of resistivity values is possible for clay: $300-10,000$ (ohm-m). With this standard, locations 1 and 2 having resistivity values of 25.01-419.22ohm-m (conductivity 0.002 - 0.194 (ohm-m) ${ }^{1}$ and 5.5-1246.57 ohm-m (conductivity $=0.0002-0.001$ $(\mathrm{ohm}-\mathrm{m})^{-1}$ ) respectively could be classified as clay. Sample 3 recorded a resistivity value of $1.00-22,787.39 \mathrm{ohm}-\mathrm{m}$ $\left(\right.$ conductivity $\left.=0.00004-1.00 \quad(\mathrm{ohm}-\mathrm{m})^{-1}\right)$ thus, was classified as silt/sand considering the range of resistivity values for silt and sand of 2,650-24,000 ohm-m and 9,60045,250 ohm-m (Kaufman and Hoekstra (2001) respectively. These values revealed soil overlap between the resistivity results of these two benchmark samples.

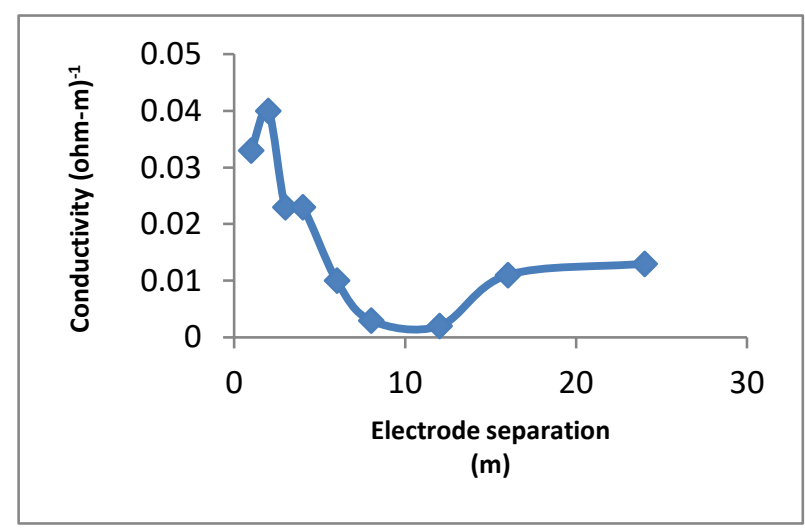

Fig. 2: Profile 1, Ededimeji along Akoda Road, Ede

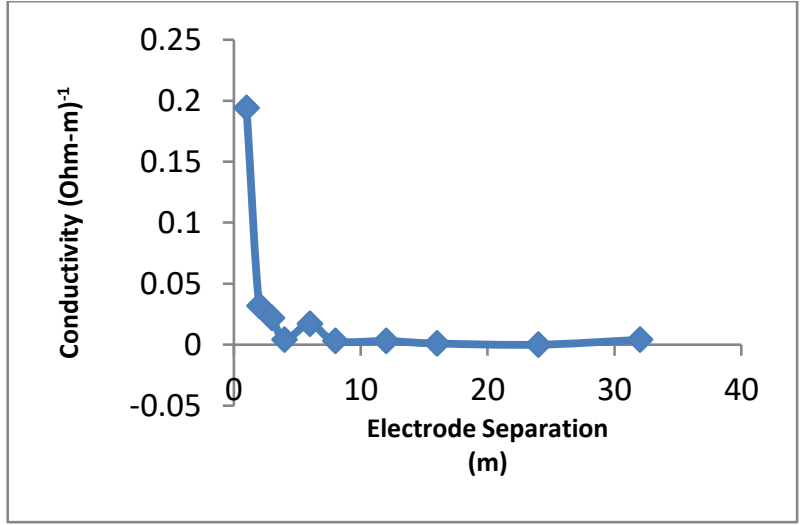

Fig. 3: Profile 2, Along Iwo-Osogbo Road, Ede.

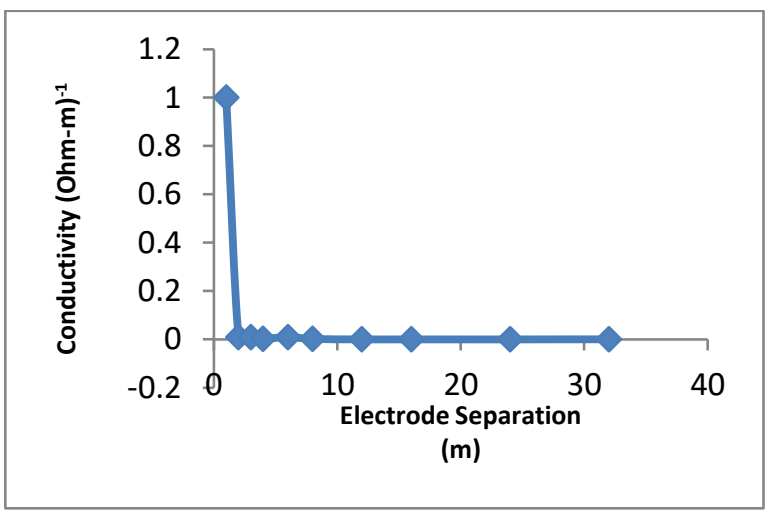

Fig. 4: Profile 3 at Cocoa Industry-Water Cooperation area, Ede.

Fig. 5 is a graph of conductivity against depth. It showed that the conductivity increased with depth but at point $0.2 \mathrm{~m}$ decreased with increase in depth. The conductivity along this profile was generally high. Fig. 6 showed a gradual fluctuation in conductivity. The graph started with high conductivity at $0.1 \mathrm{~m}$ depth and decreased to $\left.0.0 .018(\mathrm{ohm}-\mathrm{m})^{-1}\right)$ at $0.2 \mathrm{~m}$ and to $\left.0.010(\mathrm{ohm}-\mathrm{m})^{-1}\right)$ at $0.3 \mathrm{~m}$. It then gradually increased to $\left.0.04(\mathrm{ohm}-\mathrm{m})^{-1}\right)$ at depth of $0.7 \mathrm{~m}$.

Similar trend of fluctuation was also observed in Fig.7 which is the graph of conductivity against depth. It showed an increase in conductivity as the depth increased and then a slight decrease in conductivity at depth of $0.4 \mathrm{~m}$ followed by an increase in conductivity to a depth of $0.6 \mathrm{~m}$ from where a further decrease in conductivity was observed.

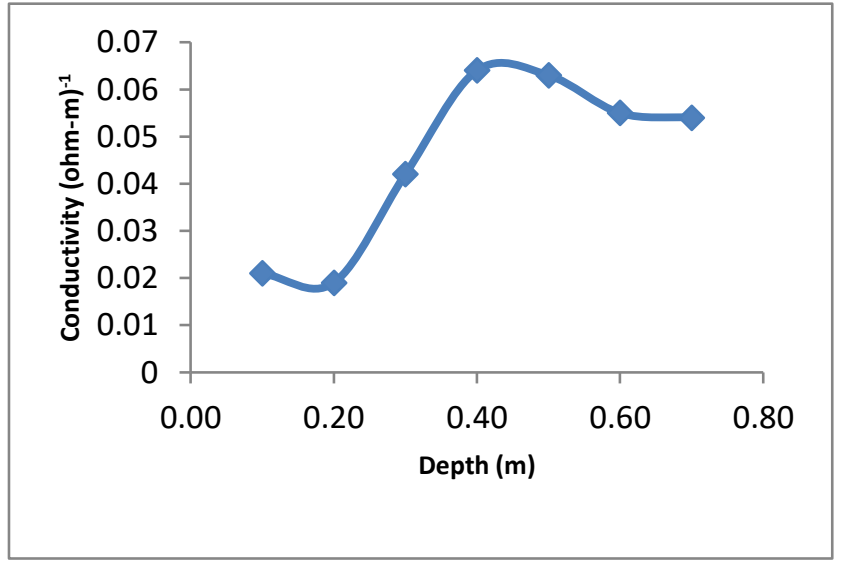

Fig. 5: Profile 1, Conductivity against Depth 


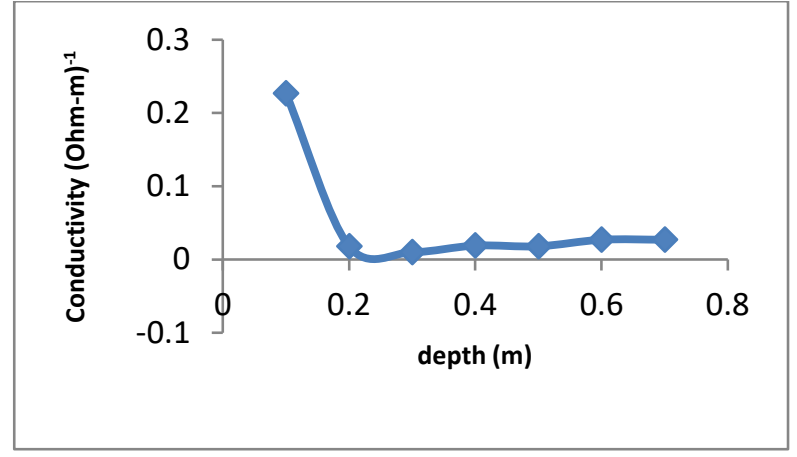

Fig. 6: Profile 2, Conductivity against Depth

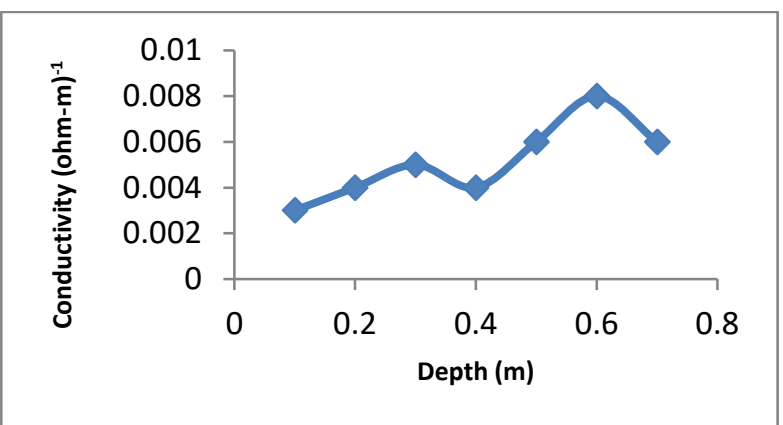

Fig. 7: Profile 3, Conductivity against Depth

The geoelectrical investigation showed that location1is an area of higher conductivity than location 2 while location 3 is the least in conductivity. It also revealed locations 1 and 2 as areas with clay soil and location 3 as an area made up of silt/sand. Thus, Locations 1 and 2 (clay) are considered good for hydrological utility while location 3 (sand) is good material for construction and engineering works.

\subsection{MOISTURE CONTENT}

The water content of the three soil samples collected were obtained as $76.92 \%, 20.1 \%$ and $5.0 \%$ for samples 1,2 and 3 respectively. The moisture content and the plastic limit for sample 2 were $20.1 \%$ and $19.5 \%$. These two values are observed to be close. Hence, based on Table 1, serial number 2, the soil is heavily over consolidated. The graphs of liquid limits revealed the liquid limits for samples 1 and 2 as $44.4 \%$ and $37.5 \%$ respectively. These values indicate the quantity of water to be added to the soils i.e., if more water is added, the liquid limit decreases or become water logged and it also reduces the numbers of blows.

Table 1. Soil condition based on moisture content (modified after Bowels, 1997)

\begin{tabular}{cll}
\hline S/No & \multicolumn{1}{c}{ Moisture content } & \multicolumn{1}{c}{ Soil condition } \\
\hline 1 & If moisture content is close to liquid limit & Normal consolidation \\
2 & If moisture content is close to plastic limit & Heavily over consolidated \\
3 & If moisture content is between liquid limit and plastic limit & Over consolidated \\
4 & If moisture content is greater than plastic limit & Nearly a viscous liquid \\
\hline
\end{tabular}

Table 2. Liquid Limit Sample 2

\begin{tabular}{lllll}
\hline Container no & E1 $_{1}$ & $\mathbf{E}_{2}$ & $\mathbf{E}_{3}$ & $\mathbf{E}_{4}$ \\
\hline Weight of can $(\mathrm{g})$ & 13.90 & 18.90 & 18.00 & 17.60 \\
Weight of wet soil + can $(\mathrm{g})$ & 30.40 & 33.50 & 31.70 & 32.20 \\
Weight of dry soil + can $(\mathrm{g})$ & 25.90 & 29.20 & 27.70 & 27.70 \\
Weight of water $(\mathrm{g})$ & 4.50 & 4.50 & 4.50 & 4.50 \\
Weight of dry soil $(\mathrm{g})$ & 12.00 & 10.30 & 9.70 & 10.10 \\
Water content \% & 37.50 & 41.74 & 41.24 & 44.55 \\
No of blows & 25.00 & 19.00 & 15.00 & 12.00 \\
\hline
\end{tabular}

Table 3. India soil classification system using plasticity index - IS 1498 - 1970 (Modified after Chand et al, 2001)

\begin{tabular}{lll}
\hline Plasticity index & Degree of plasticity & Type of soil \\
\hline $0-1$ & Non plastic & Silt \\
$1-5$ & Slight plasticity & Trace clay \\
$5-10$ & Low plasticity & Little clay \\
$10-20$ & Medium plasticity & Clay \& silt \\
$20-35$ & High plasticity & Silt clay \\
$>35$ & Very high plasticity & Clay \\
\hline
\end{tabular}

\subsection{PLASTICITY INDEX}

The difference between liquid limit and plastic limit range in the plastic state is called Plasticity index. As a basic soil property, the plasticity index is a tool used in classifying soil and in correlating with other soil properties (Raj, 2012). Following the analysis carried out, the plastic limit for Sample 2 was calculated as $19.5 \%$ and the liquid limit was $41.26 \%$, hence, the plastic index for sample 2 was obtained as $21.76 \%$. The liquid limit for sample 1 is $44.4 \%$.
Sandy soil lack plastic stage, while very fine sand shows slight plasticity (Roy and Bhalla, 2017).

Based on Table 3 and given the plasticity index of $21.76 \%$ obtained for soil sample 2 the degree of plasticity of soil sample 2 is high and the soil type is silt clay and cohesive (Chand et al., 2001; Daryati et al., 2019). 


\subsection{SPECIFIC GRAVITY}

The mass of soil solids divided by the mass of an equal volume of water is called specific gravity. It determines how suitable a soil is as a construction material. High value of specific gravity means more strength to roads and foundations while low values imply the reverse in construction.

The specific gravity obtained for the soil samples were calculated as 2.13, 2.50 and 2.40 for Samples 1, 2 and 3 respectively. Using Table 4 , these values fell within the specific gravity of 1.00-2.60 (Bowles, 2012). Hence, the soil samples are regarded as organic soil and may not be good engineering materials for road construction and foundations. Increase in specific gravity results to increase in the strength of the subgrade materials used in construction, Calfornia bearing ratio (Roy, 2016).

Table 4. Soil classification on specific gravity (Bowles,

\begin{tabular}{ll}
\multicolumn{2}{c}{ 2012). } \\
\hline Soil Type & Specific gravity \\
\hline Sand & $2.65-2.67$ \\
Silty sand & $2.67-2.70$ \\
Inorganic clay & $2.70-2.80$ \\
Soil with mica or iron & $2.75-3.00$ \\
Organic soil & $1.00-2.60$ \\
\hline
\end{tabular}

\subsection{SHRINKAGE}

The highest water content expressed as a percentage of oven-dried weight at which any further decrease in water content will not result to a decrease in volume of the soil mass is called shrinkage limit (IS: 2720 - Part 6, 1972). How suitable the soil is as a material for construction in dams, embankments, foundations and roads can be determined by its shrinkage value. Soil with finer particles have greater amount of shrinkage.

Table 5. India soil classification system using shrinkage limit IS 1498 - 1970. (Modified after Chand et al, 2001)

\begin{tabular}{cc}
\hline Shrinkage & Resistant of shrinkage \\
\hline$<5$ & Good \\
$5-10$ & Medium \\
$19-15$ & Poor \\
$>15$ & Very poor \\
\hline
\end{tabular}

Based on Table 5 and given the shrinkage results of 5.6 and $6.3 \%$ obtained for Sample 2, resistance to shrinkage is classified as medium. Soil with this value is not considered a good material for construction.

\subsection{SiEVe ANALYSIS}

The study revealed that the sieve diameter of $0.425 \mu \mathrm{m}$ for sample 1, 2 and 3 has \% passing of 93.6, 35.0 and 61.71 respectively. Adopting AASHTO soil classification system (modified after Bowles, 1978) the following deductions were made: soil Sample 1 is silt-clay material, soil Sample 2 is a granular material and soil sample 3 is silt-clay material. The representation of the classification of particles according to different sizes in the soil mass is called distribution curve (gradation curve), (Mallo and Umbugadu, 2012). The sieve analysis of the three samples revealed the soils as coarse fine, this could be as a result of the fact that the samples were taken from the top layer.

\subsection{COMPACTION}

The process of bringing soil grains closely arranged by impacting compactive energy is termed Compaction. It enhances the density, bearing capacity, shear strength of soil, and reduces its compressibility, void ratio, porosity and permeability (Kaniraj 1988; Apparao and Rao 1995; Prakash and Jain, 2002). It is a ground quality assurance technique making it an important test in construction delivery. The values of maximum dry density of each soil sample as would be obtained below is defined as the maximum range at which the soils can absorb water for compaction to occur while optimum moisture content is the range at which water can be added to each sample to make it compacted.

Table 6 showed the result of the compaction test. Based on O"Flaherty (1988) and Amadi et al., (2015), th e following range of values can be expected when the standard proctor test methods are used. Maximum dry density (MDD) between $1.44 \mathrm{mg} / \mathrm{m}^{3}$ and $1.685 \mathrm{mg} / \mathrm{m}^{3}$ and optimum moisture content (OMC) between $20-30 \%$ for clay. The MDD between $1.6 \mathrm{mg} / \mathrm{m}^{3}$ and $1.845 \mathrm{mg} / \mathrm{m}^{3}$ and OMC ranges between $15-25 \%$ for silty clay. While MDD range between $1.76 \mathrm{mg} / \mathrm{m}^{3}$ and $2.165 \mathrm{mg} / \mathrm{m}^{3}$ and $\mathrm{OMC}$ between 8 and 15\% is for sandy clay. From the above, the soil compaction test revealed that the samples could be classified as clay for sample 1 at (Ededimeji along Akoda road in Ede) while sample 2 (Along Iwo-Osogbo Road, Ede) was classified as silty clay and sample 3 at Cocoa Industry/ water cooperation area Ede could be classified as sandy clay.

Table 6. Result of Compaction Test of the Soil Samples

\begin{tabular}{cccc}
\hline Sample Location & Max. Dry Density $\left(\mathbf{g} / \mathbf{c m}^{-3}\right)$ & $\begin{array}{c}\text { Optimum Moisture } \\
\text { Content }\end{array}$ & Suspected Soil Type \\
\hline 1 & 1.45 & $15.40 \%$ & Clay \\
2 & 1.92 & $13.36 \%$ & Silty clay \\
3 & 1.95 & $9.61 \%$ & Sandy Clay \\
\hline
\end{tabular}




\section{CONCLUSION}

The field work and laboratory tests showed that the different types of soils vary in texture, water content and particles contained. Soil sample 1 measured conductivity value that ranged between $0.002-0.194(\mathrm{ohm}-\mathrm{m})^{-1}$; soil sample 2 has conductivity value of $0.0002-0.040$ (ohm$\mathrm{m})^{-1}$ while sample 3 has conductivity value ranging from $0.00004-0.01$ (ohm-m) ${ }^{-1}$. The conductivity values revealed the soil types as clay, silt/sand. These results showed that location 1is a region of higher conductivity than location 2 while location 3 has the least conductivity value.

Specific gravity test showed that samples 1, 2 and 3 have specific gravity values of 2.50, 2.13 and 2.40 respectively. Hence, all three samples are organic soil. The test of plastic limit carried out for two samples 1 and 2 showed that the soils are clay of high plasticity in AASTHO. Judged from the sieve analysis which revealed \% passing of 93.6, 35.0 and 61.71, for sample 1 at (Ededimeji along Akoda road in Ede), sample 2 (Along Iwo-Osogbo Road, Ede) and sample 3 at Cocoa Industry/ water corporation area Ede, respectively and Atterberg limit tests, the soil samples 1, 2 and 3 could be graded as silt-clay, silt-clay and granular materials respectively.

The compaction tests revealed maximum dry density (MDD) of $1.45 \mathrm{~g} / \mathrm{cm}^{3}, 1.92 \mathrm{~g} / \mathrm{cm}^{3}$ and $1.95 \mathrm{~g} / \mathrm{cm}^{3}$, for the three soil samples and optimum moisture content (OMC) of $15.40 \%, 13.36 \%$ and $9.61 \%$ respectively, thereby classifying sample 1 as clay, sample 2 as silt clay and sample 3 as sandy clay. Compaction test an important test in construction industry as it enhances the bearing capacity and consolidation of soils and ensures stability of structures. Finally, the geoelectric survey and analysis conducted in this study revealed that the soil type found in Ede, southwest Nigeria could be classified as silt-clay, sandy clay, clay and sand. Locations 1 and 2 (clay) are considered good for hydrological utility while location 3 (sandy) is a good material for construction and engineering works. The study has provided a base data for soil classification in the area.

\section{REFERENCES}

Amadi A.N., Akande W. G., Okunlola I. A., Jimoh M.O., and Francis Deborah G.(2015): Assessment of the Geotechnical Properties of Lateritic Soils in Minna, North Central Nigeria for Road design and Construction. American Journal of Mining and Metallurgy 3(1): 15-20.

Apparao, K.V.S. and Rao, V.C.S.(1995): Soil Testing Laboratory Manual and Question Bank, Universal Science Press, New Delhi

Archie, G.E., 1942. The electrical resistivity log as an aid in determining some reservoir characteristics. Trans. AM. Inst. Min. Metall. Pet. Eng. $146,54-62$

Besson, A., Cousin, I., Samouëlian, A., Boizard, H., \& Richard, G. (2004). Structural heterogeneity of the soil tilled layer as characterized by $2 \mathrm{D}$ electrical resistivity surveying. Soil and Tillage Research, 79(2), 239249.

Bowles, J.E (1997): Engineering properties of soil and their measurement, $5^{\text {th }}$ international edition McGraw-Hill in corporation. $1175 \mathrm{p}$.

Bowles, J. E. (2012): Engineering Properties of Soils and their Measurements, 4th edition, McGraw Hill Education (India) Private Limited, New Delhi.

Chand, S., M. Anwar and D. D. Patra. (2001). Influence of combined application of farm yard manure and inorganic fertilizers on herb, essential oil yield and nutrients accumulation in menthol mint (Mentha arvensis). J. Med. Arom. Plants Sci., 23: 29-34.
Dahlin, T. (2001). The development of DC resistivity imaging techniques. Computers \& Geosciences, 27(9), 1019-1029.

Daryati D., Widiasanti I., E. Septiandini, M. A. Ramadhan, K. A. Sambowo and Purnomo, A. (2019): Soil characteristics analysis based on the unified soil classification system. Annual Applied Science and Engineering Conference, Journal of Physics, doi:10.1088/17426596/1402/2/022028.

Everett, M. E. (2013). Near-surface applied geophysics Cambridge University Press.

Huat, B. B. K., Prasad,A., Asadi,A. and Kazemian, S. (2013):Geotechnics of organic soils and peat, CPI Group (UK) Ltd., Croydon, UK

IS: 2720 - Part 6, 1972, Determination of shrinkage factors, BIS, New Delhi.

Kaniraj, S.R. (1988): Design Aids in Soil Mechanics and Foundation Engineering, McGraw Hill Education (India) Pvt Limited, New Delhi

Kaufman, A. A., \& Hoekstra, P. (2001). Electromagnetic soundings Elsevier Science B.V.

Llopis, J., \& Simms, J. (2007). Geophysical surveys for assessing levee foundation conditions, feather river levees, Marysville, CA. Symposium on the application of geophysics to engineering and environmental problems; Environment and Engineering Geophysical Society, pp. 82-89

Lowrie William (2007): Fundamentals of Geophysics Second Edition, Cambridge University Press.

Mallo, S.J. and Umbugadu, A.A., 2012, Geotechnical study of the properties of soils: a case study of Nassarawa - Eggon town and Environs, Northern Nigeria., CJEarthSci., 7 (1), 40 - 47.

Ngah, S.A. and Nwankwoala, H.O.,(2013): Evaluation of geotechnical properties of the sub-soil for shallow foundation design in Onne, Rivers State, Nigeria., The IJES., 2 (11), 08 -16.

Nwankwoala, H.O. and Amadi, A.N., (2013): Geotechnical investigation of sub-soil and rock characteristics in parts of Shiroro-MuyaChanchaga area of Niger State, Nigeria., IJEE., 6(1), 8 - 17.

O'Flaherty, C. A., (1988). Highway Engineering. Vol. 2, Edward Amold Publishers, London UK.

Oghenero, A.E., Akpokodje, E.G. and Tse, A.C., (2014): Geotechnical properties of subsurface soils in Warri, Western Niger Delta, Nigeria., Journal of Earth Sciences and Geotechnical Engineering., 4(1), 89 - 102.

Palacky, G. (1988): Resistivity characteristics of geologic targets. Electromagnetic methods in applied geophysics, Society of Exploration Geophysicists. pp. 52-129

Piegari, E., \& Maio, R. D. (2013). Estimating soil suction from electrical resistivity. Natural Hazards and Earth System Sciences, 13(9), 23692379.

Prakash, S. and Jain, P.K.(2002): Engineering Soil Testing, Nem Chand \& Bros, Roorkee, 2002.

Raj, P. P. (2012): Soil Mechanics and Foundation Engineering, Dorling Kindersley (India) Pvt. Ltd., New Delhi.

Rhoades, J.D., Manteghi,V., Shouse, P.J. and Alves, W.J. (1989): Estimating soil salinity from saturated soil-paste electrical conductivity. Soil Sci. Soc. Am. J. 53:428-433.

Roy, S. (2016) Assessment of soaked California Bearing Ratio value using geotechnical properties of soils, Resources and Environment., 6(4), 8087.

Roy Surendra and Bhalla Sanjeev Kumar (2017): Role of Geotechnical Properties of Soil on Civil Engineering Structures Resources and Environment 2017, 7(4): 103-109DOI: 10.5923/j.re.20170704.03.

Scollar, I., Tabbagh, A., Hesse, A., Herzog, I., 1990. Archaeological Prospecting and Remote Sensing, 674 pp.

Seladji, S., Cosenza, P., Tabbagh, A., Ranger, J., \& Richard, G. (2010). The effect of compaction on soil electrical resistivity: A laboratory investigation. European Journal of Soil Science, 61(6), 1043-1055.

Van Genuchten, M. T. (1980): A closed-form equation for predicting the hydraulic conductivity of unsaturated soils. Soil Science Society of America Journal, 44(5), 892-898.

Wenner, F. C. (1915): A method of measuring earth resistivity, vol.258, pp. 469-478, United State Bureau of Standards, Scientific Paper,1915.

Youdeowei, P.O. and Nwankwoala, H.O., (2013): Suitability of soils as bearing media at a freshwater swamp terrain in the Niger Delta., J. Geol. Min. Res., 5(3), $58-64$ 